\title{
Relationship between Body and Otolith Morphological Characteristics of Sabre Squirrelfish (Sargocentron spiniferum) from the Southern Red Sea: Difference between Right and Left Otoliths
}

\author{
Yassein A. A. Osman ${ }^{1}$, Kélig Mahé ${ }^{2, *}{ }^{\circledR}$, Samia M. El-Mahdy $\left.{ }^{1}{ }^{(}\right)$, Ashraf S. Mohammad ${ }^{1}$ and Sahar F. Mehanna ${ }^{1}$ \\ 1 National Institute of Oceanography and Fisheries, NIOF, Cairo 11694, Egypt; \\ yasseinahmed66@yahoo.com (Y.A.A.O.); samia_mohsen2004@yahoo.com (S.M.E.-M.); \\ ashrafgro@yahoo.com (A.S.M.); sahar_mehanna@yahoo.com (S.F.M.) \\ 2 Ifremer, Fisheries Laboratory, Sclerochronology Centre, 62200 Boulogne-Sur-Mer, France \\ * Correspondence: kelig.mahe@ifremer.fr; Tel.: +33-321-995-602
}

\section{check for}

updates

Citation: Osman, Y.A.A.; Mahé, K.; El-Mahdy, S.M.; Mohammad, A.S.; Mehanna, S.F. Relationship between Body and Otolith Morphological Characteristics of Sabre Squirrelfish (Sargocentron spiniferum) from the Southern Red Sea: Difference between Right and Left Otoliths. Oceans 2021, 2, 624-633. https:// doi.org/10.3390/oceans2030035

Academic Editor: Michael W. Lomas

Received: 23 July 2021

Accepted: 30 August 2021

Published: 7 September 2021

Publisher's Note: MDPI stays neutral with regard to jurisdictional claims in published maps and institutional affiliations.

Copyright: (c) 2021 by the authors. Licensee MDPI, Basel, Switzerland. This article is an open access article distributed under the terms and conditions of the Creative Commons Attribution (CC BY) license (https:/ / creativecommons.org/licenses/by/ $4.0 /)$.

\begin{abstract}
Otolith morphology analysis is one of the main tools used for fish or fish stock identification. Moreover, otolith shape can also be used in animal dietary studies (stomach content) for the identification of prey fishes and their size according to the relationship between fish and otolith sizes. In the present study, the relationship between fish length and otolith morphological dimensions was investigated for the sabre squirrelfish, Sargocentron spiniferum (Forsskål, 1775) (family: Holocentridae). Samples of 185 fish were collected from the coast of the Red Sea, Egypt. To analyze the relationship between fish and otolith, otolith morphometric measurements (length, width, area, perimeter, weight, sulcus, and ostium) and shape factors (aspect ratio, compactness, form factor, rectangularity, roundness, ellipticity, squareness) describing the outline shape were extracted using image analysis. Generalized linear models were applied for the relationship between body length and each otolith morphology feature. From the relationships between the total length of fish and fourteen morphology features, only otolith length, caudal length, and squareness were significantly correlated with fish size. Our results provide more information for the relationship between fish length and otolith morphometric features.
\end{abstract}

Keywords: fish size; otolith shape; head side; Sargocentron spiniferum; red sea; asymmetry

\section{Introduction}

The sabre squirrelfish Sargocentron spiniferum (Forsskål, 1775) is a member of the family Holocentridae, which is mainly distributed in the Indo-Pacific from the Red Sea and East Africa to the Hawaiian Islands and Ducie Islands extending south to Australia. They can be diagnosed by several morphological criteria: head and body red, scale edges silvery white, spinous dorsal crimson in color, other fins orange-yellow, and vertically oblong fin crimson spot on preopercle behind eye [1]. This solitary species inhabits a variety of reef zones from reef flats to lagoon and seaward reefs to a depth of at least $120 \mathrm{~m}$ in New Caledonia, north to southern Japan and the Ogasawara Islands [1-3]. This fish occurs under ledges during the day [3], and when smaller in size, this fish inhabits shallow, protected areas. It is a nocturnal fish that feeds on crabs, shrimp, and small fishes [4]. The trophic level was estimated at 3.8 in Moorea island (French Polynesia [5]). Only one growth study has previously been carried out in the Egyptian Red Sea with the oldest specimen at seven years old [6]. Moreover, the maximum length and weight data are known (total length of $45.8 \mathrm{~cm}$ and total weight of $2600 \mathrm{~g}$ ) and showed that this species is the largest species of squirrelfish and the highest-bodied Sargocentron species. In 2014, among 200 tons of total world catches of sabre squirrelfish (Sargocentron spiniferum), the catches from the Northern and Central Red Sea were in the order of 55 tons, which identifies this geographical area 
as the largest fishery for this species (source FishStat database). Its level of exploitation appeared to be controlled with the level of catches close to the maximum sustainable yield (MSY) which identified a hypothetical equilibrium state between the exploited population and the fishing activity [7]. This species is commercially exploited mainly by small-scale fishing in the Red Sea.

Many researchers have used the clear and distinct growth increments of calcified structures to study the age and growth of fishes [8,9]. Among calcified structures, otoliths, which are located in right and left inner ears of fishes, are the most used in the study of fish biology, ecology, and fisheries science [10-12]. Each fish present three pairs of otoliths. The sagittae, the largest of the three pairs of otoliths, are widely used to describe age and growth in fish [9]. In one ageing study on Sargocentron spiniferum, the whole sagittal otolith was used to determine the relationship between age and size of fish. Fish use their otoliths for balance and hearing, sensing small changes in the direction and pressure of water. In fisheries science, otoliths are also used to estimate movement, varied habitat, population dynamics, and trophic level for fish species [12-20].

Otolith morphology is used to recognise fish species in taxonomic, phylogenetic, paleoichthyological, and dietary studies [21-24]. Moreover, to follow the growth of fish from the otolith, there must be a proportional relationship between the growth of the fish and the otolith. This kind of relationship can even be used to predict the age directly without observing growth increments [25]. One recent study showed, however, that directional asymmetry between right and left otoliths within individuals could affect the results from the otolith shape analysis as a tool to identify the stocks [26]. However, there are no studies on the relationship between $S$. spiniferum growth and otolith growth. Consequently, the aim of the present work was to estimate the relationship between fish size and otolith outline features according to the location of the otolith, i.e., left versus right inner ear for S. spiniferum from the Egyptian waters of the Red Sea to answer three questions:

Is there a morphological difference between the right and left otoliths for this species?

Is it possible to use all the size parameters of the otolith equally to correlate fish growth with otolith growth for this species?

Is it possible to associate the otolith shape (i.e., shape indices) with the body length for this species?

These questions need to be answered before the otolith can be used primarily to estimate the growth of this species.

\section{Materials and Methods}

Fish species were randomly collected from the commercial catch of the hook and line fishery at Shalateen fishing ground from the southern Red Sea, which is located $520 \mathrm{~km}$ south of Hurghada (Figure 1), Egypt, between March 2018 and February 2019. A total of 185 individuals was sampled.

In the laboratory, total fish length (TL) was measured to the nearest $0.1 \mathrm{~cm}$; then, the sex was determined from macroscopic observation of gonads. The males show that the thin testis and the mature females present a continuum of large oocyte in the ovary. The sampling was composed of 76 females, 73 males, and 36 specimens with undetermined sex. The total length of the species ranged between 17.7 and $45.8 \mathrm{~cm}$. Sagittal otoliths (370 paired left and right otoliths) were extracted from the inner ear of 185 S. spiniferum, cleaned and dried. Otolith weight (OW) for each head side was measured using a digital balance AS220 k/1 to the nearest $0.0001 \mathrm{~g}$. Otolith images were captured using a Euromex CMEX-10 PRO camera with a stereomicroscope. The following otolith measurements: length $(\mathrm{OL}, \mathrm{mm})$, width $(\mathrm{OH}, \mathrm{mm})$, area $\left(\mathrm{OA}, \mathrm{mm}^{2}\right)$, perimeter $(\mathrm{OP}, \mathrm{mm})$, sulcus length (SU, $\mathrm{mm}$ ), and ostium length (OS, $\mathrm{mm}$ ) were taken using image processing systems (Image J analysis software, [27]; detailed descriptions are in Figure 2). 


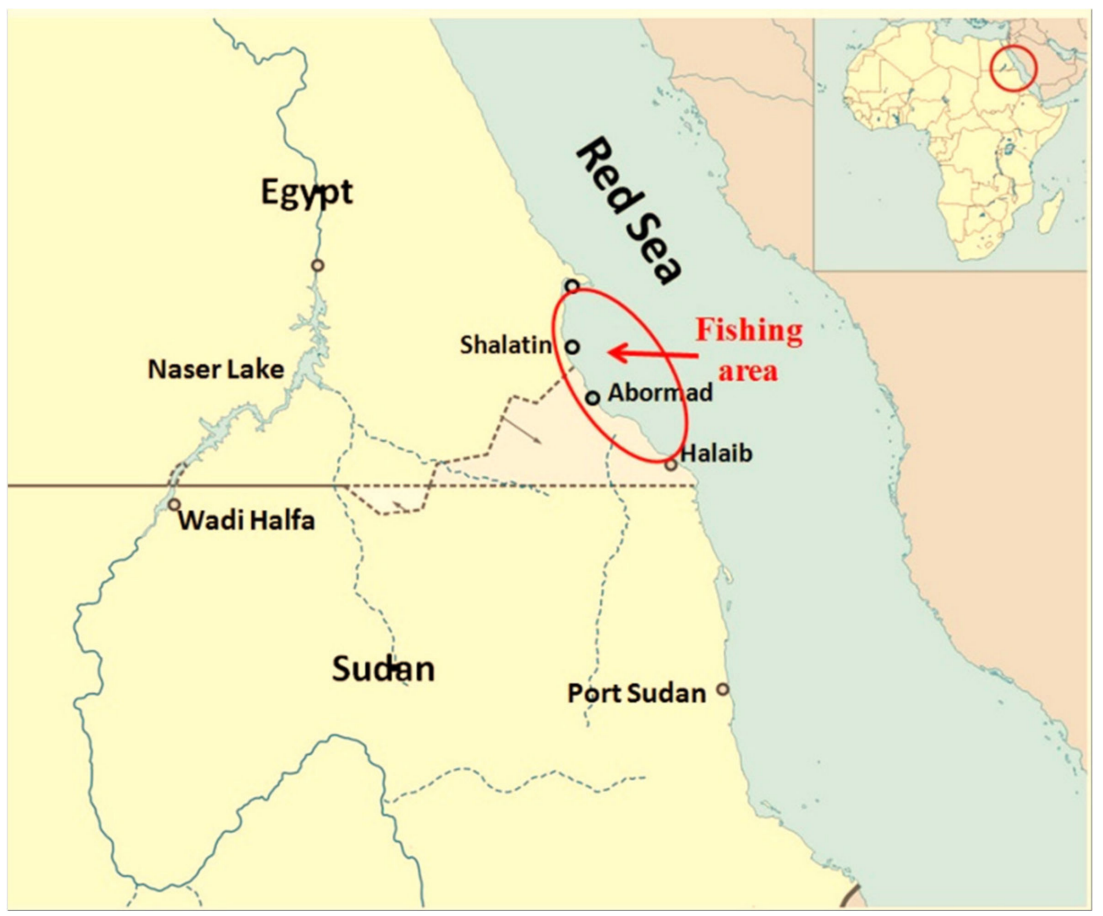

Figure 1. Egyptian Red Sea map showing the studied Shalateen area.

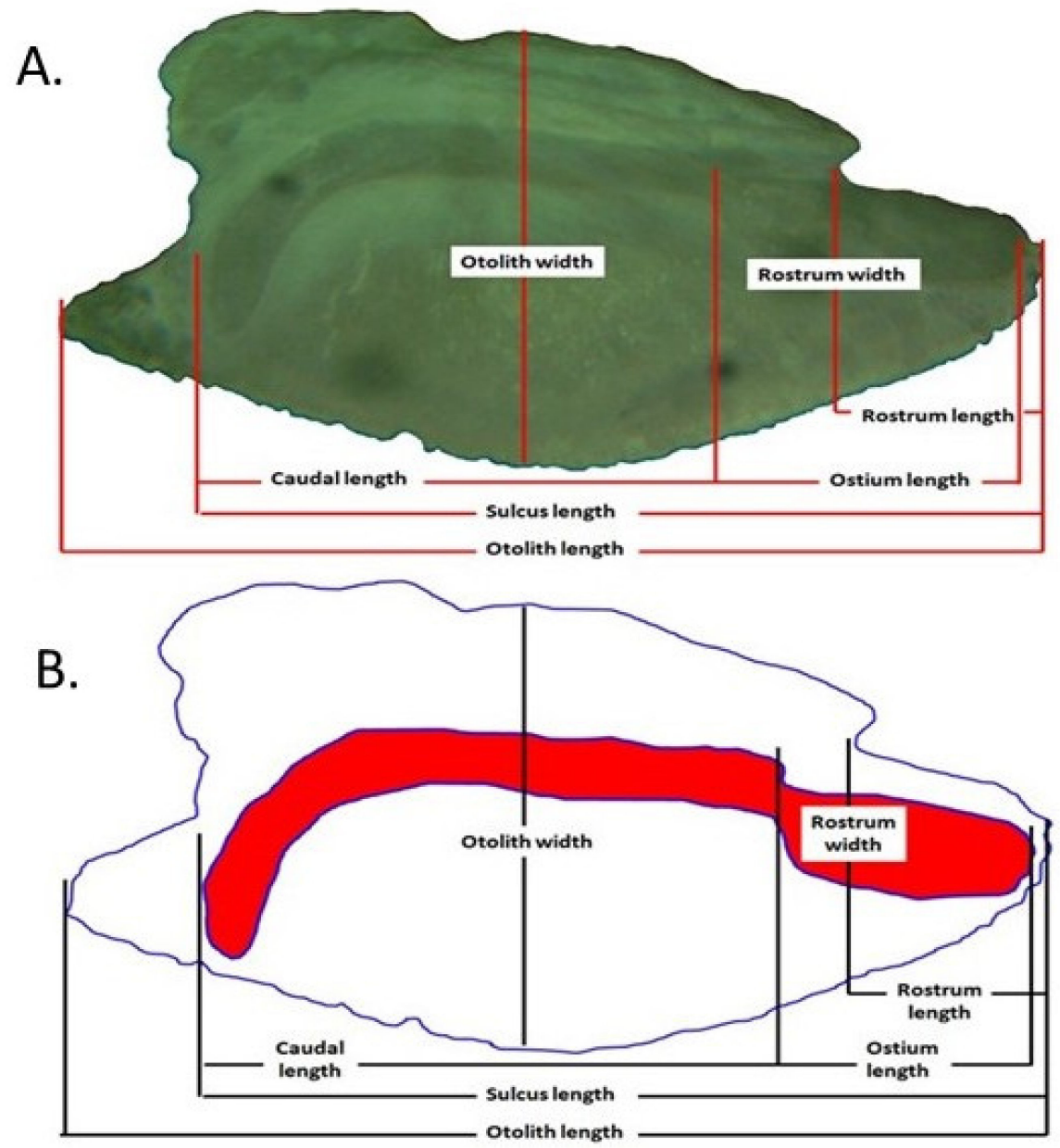

Figure 2. Otolith image (A) and scheme (B) of Sargocentron spiniferum illustrating various features of the otolith measurements. The red area shows the sulcus acusticus. 
From these size parameters, the following shape indices were calculated: form factor $(\mathrm{FF})$, aspect ratio (AR), circularity $(\mathrm{CI})$ rectangularity $(\mathrm{RE})$, roundness (RO), ellipticity (EL), compactness (C), and squareness (SQ) [17,28-32]. The formulae of these shape index factors (FF, C, AR, CI, RO, RE, EL, and SQ) are presented in Table 1.

Table 1. Size dimension parameters and shape indices of otolith used to describe S. spiniferum otolith characteristics.

\begin{tabular}{ccc}
\hline Size Parameters & \multicolumn{2}{c}{ Shape Indices } \\
\hline Length:OL & Circularity: & $C I=O P / O A^{2}$ \\
Width:OH & Ellipticity: & $E L=(O L-O H) /(O L+O H)$ \\
Perimeter:OP & Roundness: & $R O=4 O A / \pi O L^{2}$ \\
Area:OA & Aspect ratio: & $A R=O L / O H$ \\
Weight: OW & Rectangularity: & $R E=O A /(O L \cdot O H)$ \\
Sulcus:OSL & Form-factor: & $F F=4 \pi O A / O P^{2}$ \\
Ostium:OOs & Compactness: & $C O=O P^{2} / O A$ \\
Cauda:OCu & Squareness: & $S Q=O A /(O L \cdot O W)$ \\
\hline
\end{tabular}

All analyses were performed on the base-10 logarithm of the body and otoliths data to apply the generalized linear model. Subsequently, the relationship of fish length with each otolith feature (size parameters or shape indices) was modelled according to the sex and side:

$\mathrm{TL} \sim$ Otolith feature + Sex + Side + Otolith feature:Sex + Otolith feature:Side

The normality and the homoscedasticity of the residuals were assessed by visual inspection of diagnostic plots. The significance of explanatory variables was tested by likelihood ratio tests between nested models while respecting marginality of the effects (type 2 tests [33]) that are supposed to follow a $\chi^{2}$ distribution under the null hypothesis while correcting for multiple comparisons using a Bonferroni procedure. Statistical analyses were performed in the R statistical environment [33] stats package [34].

\section{Results}

A general pattern of $S$. spiniferum sagittae can be recognized in adult individuals: the otolith shape of $S$. spiniferum is ovate with sinuate margins, and is elongated, reflecting slower growth of the dorso-ventral axis compared to the antero-posterior axis. The dorsoventral axis has the highest growth, with a much higher distance than that observed on the antero-posterior axis with the rounded posterior area and the lobed anterior area. The sulcus acousticus is ostial with the heterosulcus and ostium formed by a short, funnel-like ostium that opens to the anterior margin, and closed, tubular cauda at least two times larger than the ostium (Figure 2). Descriptive statistics for left and right otoliths of S. spiniferum are given in Table S1.

The total length of the species ranged between 17.7 and $45.8 \mathrm{~cm}$. Analysis of the relationships between fish length and fourteen otolith shape descriptors using a generalized linear model showed that there is a significant relationship between eight otolith parameters (ostium length, caudal length, otolith area, otolith perimeter, compactness, form factor, circularity, and squareness) with the total length of fish. There is no sex effect on the relationship between fish length with each otolith feature (size parameters or shape indices). For side effect, only the relationship of body length with otolith length, caudal length, and squareness $(p<0.05)$ was significant for the right and left otolith (Table 2$)$. The relationship between TL and each otolith descriptor according to the significance of side effect for S. spiniferum are given in Table S2. 
Table 2. Generalized linear models for the relationship between fish length and each otolith variable for S. spiniferum from the Red Sea with the significance (TL) and Sex and Side effects (observed from the interaction between Otolith feature and sex or side in the GLM: Otolith feature:Side). Grey case shows the significant effect $(p<0.05)$. Allometric equations between TL and each otolith descriptor was shown according to the significance of side effect, OL, otolith length; OH, otolith width; SU, sulcus; OS, ostium; OA, otolith area; OP, otolith perimeter, FF, form factor; $\mathrm{AR}$, aspect ratio; $\mathrm{C}$, compactness; $\mathrm{RE}$, rectangularity, $\mathrm{RO}$, roundness; $\mathrm{EL}$, ellipticity; $\mathrm{C}$, circularity $\mathrm{y} ; \mathrm{SQ}$, squareness.

\begin{tabular}{|c|c|c|c|c|}
\hline Otolith Descriptor & TL & Sex Effect & Side Effect & $\begin{array}{c}\text { Allometric Equations between } \\
\text { Otolith Descriptor and TL }\end{array}$ \\
\hline OL & 0.482 & 0.306 & 0.010 & $\begin{array}{c}\text { Left side } \mathrm{OL}=2.833 \times \mathrm{TL}^{0.418} \\
\text { Right side } \mathrm{OL}=2.631 \times \mathrm{TL}^{0.439}\end{array}$ \\
\hline $\mathrm{OH}$ & 0.274 & 0.791 & 0.148 & $\mathrm{OH}=1.091 \times \mathrm{TL}^{0.563}$ \\
\hline Sulcus length & 0.078 & 0.534 & 0.336 & $\mathrm{SU}=1.549 \times \mathrm{TL}^{0.554}$ \\
\hline Ostium length & 0.008 & 0.823 & 0.621 & $\mathrm{OS}=0.441 \times \mathrm{TL}^{0.656}$ \\
\hline Caudal length & $<0.001$ & 0.201 & $<0.001$ & $\begin{array}{c}\text { Left side } \mathrm{CA}=1.154 \times \mathrm{TL}^{0.491} \\
\text { Right side } \mathrm{CA}=1.119 \times \mathrm{TL}^{0.454}\end{array}$ \\
\hline $\mathrm{OA}$ & $<0.001$ & 0.133 & 0.446 & $\mathrm{OA}=4.625 \times \mathrm{TL}^{0.777}$ \\
\hline OP & 0.007 & 0.114 & 0.986 & $\mathrm{OP}=7.104 \times \mathrm{TL}^{0.441}$ \\
\hline AR & 0.973 & 0.325 & 0.853 & $\mathrm{AR}=0.400 \times \mathrm{TL}^{0.135}$ \\
\hline $\mathrm{C}$ & 0.023 & 0.402 & 0.703 & $\mathrm{C}=10.909 \times \mathrm{TL}^{0.105}$ \\
\hline FF & 0.001 & 0.345 & 0.388 & $\mathrm{FF}=0.288 \times \mathrm{TL}^{-0.105}$ \\
\hline $\mathrm{RE}$ & 0.301 & 0.413 & 0.642 & $\mathrm{RE}=1.552 \times \mathrm{TL}^{-0.215}$ \\
\hline $\mathrm{RO}$ & 0.523 & 0.222 & 0.263 & $\mathrm{RO}=0.790 \times \mathrm{TL}^{-0.08}$ \\
\hline EL & 0.574 & 0.289 & 0.091 & $\mathrm{EL}=0.638 \times \mathrm{TL}^{-0.308}$ \\
\hline $\mathrm{CI}$ & $<0.001$ & 0.402 & 0.802 & $\mathrm{CI}=10.909 \times \mathrm{TL}^{-0.105}$ \\
\hline SQ & $<0.001$ & 0.413 & $<0.001$ & $\begin{array}{r}\text { Left side } \mathrm{SQ}=1.532 \times \mathrm{TL}^{-0.211} \\
\text { Right side } \mathrm{SQ}=1.573 \times \mathrm{TL}^{-0.219}\end{array}$ \\
\hline
\end{tabular}

The correlation between fish total length and otolith growth showed that with an increase in the total length, the following factors of otolith size also increased: ostium length, caudal length, otolith area, and otolith perimeter (Figure 3). The relationship between body length and the aspect ratio was, however, close to 1 , confirming that the otolith of S. spiniferum was oval. Among the shape indices, only four showed a significant relationship with total length. If the circularity and compactness increased with the body size, this trend was reversed for the other shape indices (Squareness and Form Factor, Figure 3). 

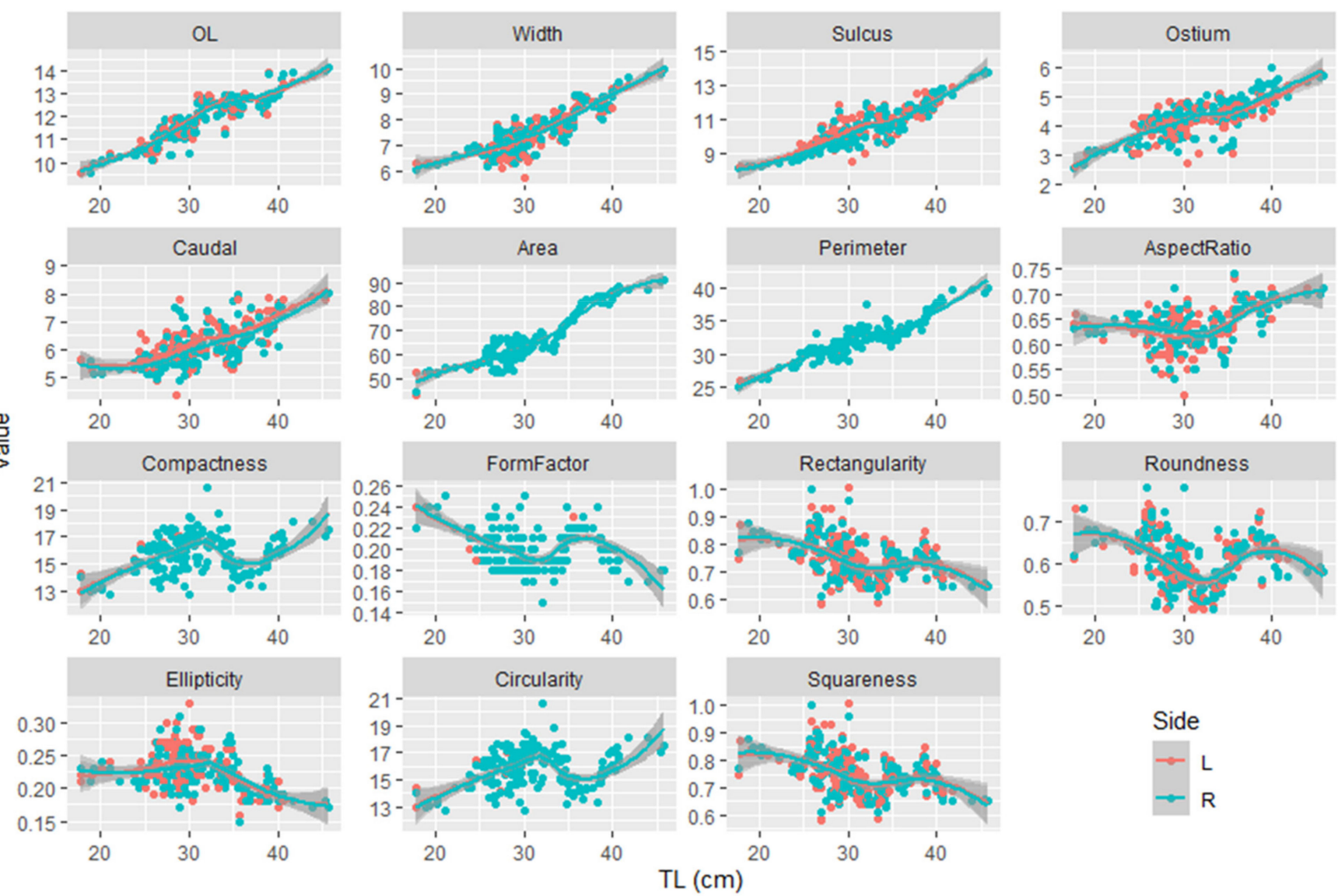

Figure 3. Relationships of body length with the otolith morphological structures (red points = left otolith, and green points = right otolith) according to the side of $S$. spiniferum captured from Shalateen, Egypt, Red Sea.

\section{Discussion}

The sabre squirrelfish Sargocentron spiniferum (Forsskål, 1775) contributes to important fisheries, especially the small artisanal fisheries at the Shalateen fishing ground, Red Sea, Egypt. Basic data on the biology and dynamics of the species are essential for successful stock assessment and consequently in fisheries management. The observed fish length and shape of the otolith in this study should encourage more research to verify the essential role of otolith morphometric measurements in fish stock identification. If the relationship between fish and otolith growth has been observed for S. spiniferum as in many other fish species, it should be noted that simple descriptors such as otolith length and width are not usable for this species, but it is necessary to use more integrative factors of otolith size such as perimeter or area. In the same way, the descriptors (ostium length, caudal length) of the sulcus acusticus (a depression situated in the proximal surface of the sagitta and it allows the connection between the sensorial macula and the otolith) are also usable to describe the relationship between body and otolith size.

The morphology of the sulcus acusticus could be linked to ecomorphologic (functional and environmental) and phylogenetic aspects [35]. Previous studies have focused mainly on the relationship between only otolith length and fish length [11,36-40]. For S. rubrum, sampling was done in the southeastern Mediterranean Sea (Arsuz coast) and the relationship between body size and otolith parameters (length and width) were estimated [31]. The authors observed correlations between otolith length and width in relation to fish length, but no side effect on these relationships. In our study, the results of generalized linear models showed that the relationship between otolith parameters and fish length can be affected by the choice of the otolith (right and left otoliths). Our study on S. spiniferum from the southern Red Sea showed in particular that the relationship between otolith and 
fish length was side-dependent. This difference could be explained by either the difference in species (S. rubrum vs. S. spiniferum) or the difference in environment (Red Sea vs. Mediterranean Sea). The recent review analyzing 91 published studies on marine fish stock identification based on otolith shape analysis identified the significant bilateral asymmetry for Liza ramada, Boops boops, Diplodus annularis, Diplodus puntazzo, Clupea harengus, and Scomberomorus niphonius. Conversely, the symmetry between left and right otolith shapes was observed for other fish species as Gadus morhua, Synechogobius ommaturus, Coryphaena hippurus, Xiphias gladius, Scomber scombrus, and Lutjanus kasmira [41]. Within a species, the level of asymmetry between left and right otoliths may vary greatly between several habitats [42]. For S. spiniferum from the southern Red Sea, if the relationship between fish size and otolith size is used, it is necessary to identify the used side to avoid introducing a bias in the results. Moreover, otolith asymmetry could be considered as a sensitive indicator of fish health that directly affects the fish performance, because otoliths are essential to balance and hearing $[43,44]$.

Based on the present data, the relationships between $\mathrm{TL}$ and $\mathrm{AR}, \mathrm{CO}$, and $\mathrm{CI}$ were determined as linear, while the relationships among TL and FF, RE, RO, EL, and SQ were determined as nonlinear. The shape of otolith from different geographical areas is, however, influenced by both environmental parameters (e.g., salinity, temperature) and biotic parameters, for example, prey availability, and depends on the individual genotype [14,45-47]. Consequently, an interaction of environmental and genetic fluctuation generates the morphological variance in otolith shape that may allow the differentiation of stock units, but also requires the shape to be tested locally before using shape data from another geographical area. The evolution of otolith shape features during ontogeny is very different from one species to another. Several otolith shape features as otolith width and height depend mainly on the environment [48]. Other otolith shape features could be linked strongly to inner ear functioning and morphology. The sulcus, caudal, and ostium lengths are closely related to the development of the macula $[48,49]$. However, the factors that affect the shapes are not fully understood and have not yet been investigated deeply $[49,50]$. A recent and on-going work showed that the ontogenetic trajectory of otolith shape could be impacted by the environmental disturbance during the early life stage [51].

The relationships between fish size and otolith shape indices demonstrate the high variability in fish length and morphometric parameters, indicating that the otolith of $S$. spiniferum is oval. The results of this study on the fish size and otolith morphometric parameters are useful for further research on verifying the role of otoliths in the identification, discrimination, and taxonomic classification of fish. Finally, the estimation of the generalized linear models in the present work may be a good tool to study the relationship between fish and otolith morphometric features, which are used for fish population dynamics, stomach contents analyses of piscivorous predators, paleontological composition, and yield estimates.

Supplementary Materials: The following are available online at https: / www.mdpi.com/article / 10.3390/oceans2030035/s1, Table S1. Summary of descriptive statistics and paired t-test results for left and right otoliths of S. spiniferum $(n=185)$. Table S2. Relationship between TL and each otolith descriptor was showed according to the significance of side effect, OL, otolith length; $\mathrm{OH}$, otolith width; SU, sulcus; OS, ostium; OA, otolith area; OP, otolith perimeter, FF, form factor; $\mathrm{AR}$, aspect ratio; $C$, compactness; $\mathrm{RE}$, rectangularity, $\mathrm{RO}$, roundness; $\mathrm{EL}$, ellipticity; $\mathrm{C}$, circularity y; $\mathrm{SQ}$.

Author Contributions: Conceptualization, methodology Y.A.A.O., S.M.E.-M., A.S.M. and S.F.M.; formal analysis, Y.A.A.O. and K.M.; writing-original draft preparation, Y.A.A.O.; writing-review and editing, K.M. All authors have read and agreed to the published version of the manuscript.

Funding: No specific funds for this study.

Institutional Review Board Statement: Ethical review and approval were waived for this study, because the fish were obtained from fisheries and were already dead when the otoliths were extracted. 
Informed Consent Statement: Not applicable.

Data Availability Statement: The data presented in this study are available on request from the corresponding author.

Acknowledgments: We would especially thank K. M. MacKenzie for the valuable help in editing this manuscript.

Conflicts of Interest: The authors declare no conflict of interest.

\section{References}

1. Randall, J.; Greenfield, D. Holocentridae: Squirrelfishes (soldierfishes). In FAO Species Identification Guide for Fishery Purposes: The Living Marine Resources of the Western Central Pacific; FAO: Rome, Italy, 1999; pp. 2225-2256.

2. Randall, J.E. Zoogeography of shore fishes of the Indo-Pacific region. Zool. Stud. 1998, 37, 227-268.

3. Lieske, E.; Myers, R. Coral Reef Fishes: Caribbean, Indian Ocean and Pacific Ocean Including the Red Sea, USA. Princeton University Press: Princeton, NJ, USA, 1994.

4. Kuiter, R.H.; Tonozuka, T. Pictorial Guide to Indonesian Reef Fishes; Zoonetics: Sydney, Australia, 2001.

5. Dubois, M. Effets Combinés de la Pêche et des Perturbations Naturelles sur la Dynamique des Ecosystèmes Coralliens. Ph.D. Thesis, École Pratique des Hautes Études, Paris, France, 2019.

6. Mohammad, A.S.; Mehanna, S.F.; Osman, Y.A.A.; El-Mahdy, S.M. Age, growth and population parameters of the spiny squirrelfish, Sargocentron spiniferum (Forsskål, 1775) from Shalateen fishing area, Red Sea, Egypt. Egypt. J. Aquat. Biol. Fisheries 2020, 32, 469-480. [CrossRef]

7. Sea around US: Fisheries, Ecosystems \& Biodiversity. Available online: http://www.seaaroundus.org/data/\#/msy/30606507 (accessed on 23 July 2021).

8. Vitale, F.; Worsøe Clausen, L.; Chonchúir, G.N. Handbook of fish age estimation protocols and validation methods. ICES Coop. Res. Rep. 2019, 346, 1-180.

9. Panfili, J.; de Pontual, H.; Troadec, J.-P.; Wright, P.J. Manual of Fish Sclerochronology; Ifremer-IRD: Brest, France, $2002 ;$ pp. 1-463.

10. Tuset, V.; Lozano, I.; González, J.; Pertusa, J.; GarcíaDíaz, M. Shape indices to identify regional differences in otolith morphology of comber, Serranus cabrilla (L., 1758). J. Appl. Ichthyol. 2003, 19, 88-93. [CrossRef]

11. Mehanna, S.; Jawad, L.; Ahmed, Y.; Abu ElRegal, M.; Dawood, D. Relationships between fish size and otolith measurements for Chlorurus sordidus (Forsskål, 1775) and Hipposcarus harid (Forsskål, 1775) from the Red Sea coast of Egypt. J. Appl. Ichthyol. 2016, 32, 356-358. [CrossRef]

12. Tuset, V.M.; Lombarte, A.; Gonzalez, J.; Pertusa, J.; Lorente, M. Comparative morphology of the sagittal otolith in Serranus spp. J. Fish Biol. 2003, 63, 1491-1504. [CrossRef]

13. Campana, S.E.; Casselman, J.M. Stock discrimination using otolith shape analysis. Can. J. Fish. Aquat. Sci. 1993, 50, 1062-1083. [CrossRef]

14. Cardinale, M.; Doering-Arjes, P.; Kastowsky, M.; Mosegaard, H. Effects of sex, stock, and environment on the shape of known-age Atlantic cod (Gadus morhua) otoliths. Can. J. Fish. Aquat. Sci. 2004, 61, 158-167. [CrossRef]

15. Rooker, J.R.; Secor, D.H.; DeMetrio, G.; Kaufman, A.J.; Ríos, A.B.; Tiina, V. Evidence of trans-Atlantic movement and natal homing of bluefin tuna from stable isotopes in otoliths. Mar. Ecol.-Prog. Ser. 2008, 368, 231-239. [CrossRef]

16. Yilmaz, S.; Yazicioglu, O.; Saygin, S.A.; Polat, N. Relationships of otolith dimensions with body length of European perch, Perca fluviatilis L., 1758 from Lake Ladik, Turkey. Pakistan J. Zool. 2014, 46, 1231-1238.

17. Zischke, M.T.; Litherland, L.; Tilyard, B.R.; Stratford, N.J.; Jones, E.L.; Wang, Y.-G. Otolith morphology of four mackerel species (Scomberomorus spp.) in Australia: Species differentiation and prediction for fisheries monitoring and assessment. Fish. Res. 2016, 176, 39-47. [CrossRef]

18. Zorica, B.; Sinovi, G.; Kel, V. Preliminary data on the study of otolith morphology of five pelagic fish species from the Adriatic Sea (Croatia). Acta Adriat. 2010, 51, 89-96.

19. Sadighzadeh, Z.; Tuset, V.M.; Valinassab, T.; Dadpour, M.R.; Lombarte, A. Comparison of different otolith shape descriptors and morphometrics for the identification of closely related species of Lutjanus spp. from the Persian Gulf. Mar. Biol. Res. 2012, 8 , 802-814. [CrossRef]

20. Morat, F.; Letourneur, Y.; Nérini, D.; Banaru, D.; Batjakas, I.E. Discrimination of red mullet populations (Teleostean, Mullidae) along multi-spatial and ontogenetic scales within the Mediterranean basin on the basis of otolith shape analysis. Aquat. Living Resour. 2012, 25, 27-39. [CrossRef]

21. Tuset, V.M.; Rosin, P.L.; Lombarte, A. Sagittal otolith shape used in the identification of fishes of the genus Serranus. Fish. Res. 2006, 81, 316-325. [CrossRef]

22. Škeljo, F.; Ferri, J. The use of otolith shape and morphometry for identification and size-estimation of five wrasse species in predator-prey studies. J. Appl. Ichthyol. 2011, 28, 524-530. [CrossRef]

23. Jawad, L.A.; Hoedemakers, K.; Ibáñez, A.; Ahmed, Y.; Abu ElRegal, M.; Mehanna, S. Morphology study of the otoliths of the parrotfish, Chlorurus sordidus (Forsskål, 1775) and Hipposcarus harid (Forsskål, 1775) from the Red Sea coast of Egypt (Family: Scaridae). J. Mar. Biol. Assoc. United Kingd. 2017, 98, 819-828. [CrossRef] 
24. Disspain, M.C.F.; Ulm, S.; Gillanders, B.M. Otoliths in archaeology: Methods, applications and future prospects. J. Archaeol. Sci. Rep. 2016, 6, 623-632. [CrossRef]

25. Mahé, K.; Bellamy, E.; Delpech, J.P.; Lazard, C.; Salaun, M.; Vérin, Y.; Coppin, F.; Travers-Trolet, M. Evidence of a relationship between weight and total length of marine fish in the North-eastern Atlantic Ocean: Physiological, spatial and temporal variations. J. Mar. Biol. Assoc. UK 2018, 98, 617-625. [CrossRef]

26. Mahé, K.; Ider, D.; Massaro, A.; Hamed, O.; Jurado-Ruzafa, A.; Gonçalves, P.; Anastasopoulou, A.; Jadaud, A.; Mytilineou, C.; Elleboode, R. Directional bilateral asymmetry in otolith morphology may affect fish stock discrimination based on otolith shape analysis. ICES J. Mar. Sci. 2018, 76, 232-243. [CrossRef]

27. Rohlf, F. tpsDig 2.10; Department of Ecology and Evolution, State University of New York: Stony Brook, NY, USA, 2006.

28. Russ, J. Computer-Assisted Microscopy.-The Measurement and Analysis of Image; Plenum Press Corp: New York, NY, USA, 1990; pp. 71-79.

29. Pavlov, D.A.; Emelyanova, N.G.; Ha, V.T.; Thuan, L.T.B. Otolith morphology, age, and growth of freckled goatfish Upeneus tragula (Mullidae) in the coastal zone of Vietnam. J. Ichthyol. 2015, 55, 363-372. [CrossRef]

30. Mahe, K.; Evano, H.; Mille, T.; Muths, D.; Bourjea, J. Otolith shape as a valuable tool to evaluate the stock structure of swordfish Xiphias gladius in the Indian Ocean. Afr. J. Mar. Sci. 2016, 38, 457-464. [CrossRef]

31. Kabakli, F.; Ergüden, D. Relationships between Fish Length and Otolith Dimensions of Redcoat, Sargocentron rubrum (Forsskal, 1775) in the Southeastern Mediterranean Sea, Turkey. Turk. J. Marit. Mar. Mar. Sci. 2018, 4, 156-162.

32. Osman, A.G.M.; Farrag, M.M.; Mehanna, S.F.; Osman, Y.A. Use of otolithic morphometrics and ultrastructure for comparing between three goatfish species (family: Mullidae) from the northern Red Sea, Hurghada, Egypt. Iran. J. Fish. Sci. 2020, 19, 814-832.

33. Fox, J.; Weisberg, S. Multivariate linear models in R. An R Companion to Applied Regression; Sage Publications: Los Angeles, CA, USA, 2011.

34. R Development Core Team. R. A Language and Environment for Statistical Computing; R Foundation for Statistical Computing: Vienna, Austria, 2016.

35. Torres, G.J.; Lombarte, A.; Morales-Nin, B. Variability of the sulcus acusticus in the sagittal otolith of the genus Merluccius (Merlucciidae). Fish. Res. 2000, 46, 5-13. [CrossRef]

36. Harvey, J.T.; Loughlin, T.R.; Perez, M.A.; Oxman, D.S. Relationship Between Fish Size and Otolith Length for 63 Species of Fishes from the Eastern North Pacific Ocean; (NOAA Technical Report NMFS, 150); NOAA/National Marine Fisheries Service: Seattle, WA, USA, 2000.

37. Fossen, I.; Albert, O.T.; Nilssen, E.M. Improving the precision of ageing assessments for long rough dab by using digitised pictures and otolith measurements. Fish. Res. 2003, 60, 53-64. [CrossRef]

38. Lychakov, D.V.; Rebane, Y.T.; Lombarte, A.; Fuiman, L.; Takabayashi, A. Fish otolith asymmetry: Morphometry and modeling. Hear. Res. 2006, 219, 1-11. [CrossRef] [PubMed]

39. Morat, F.; Banaru, D.; Mérigot, B.; Batjakas, I.E.; Betoulle, S.; Vignon, M.; Lecomte-Finiger, R.; Letourneur, Y. Relationships between fish length and otolith length for nine teleost fish species from the Mediterranean basin, Kerguelen Islands, and Pacific Ocean. Cybium 2008, 32, 265-269.

40. Pavlov, D. Differentiation of three species of the genus Upeneus (Mullidae) based on otolith shape analysis. J. Ichthyol. 2016, 56, 37-51. [CrossRef]

41. Mahé, K. Sources de Variation de la Forme des Otolithes: Implications Pour la Discrimination des Stocks de Poissons. Ph.D. Thesis, Université du Littoral Côte d'Opale, Boulogne-sur-Mer, France, 2019.

42. Mahé, K.; MacKenzie, K.; Ider, D.; Massaro, A.; Hamed, O.; Jurado-Ruzafa, A.; Gonçalves, P.; Anastasopoulou, A.; Jadaud, A.; Mytilineou, C.; et al. Directional bilateral asymmetry in fish otolith: A potential tool to evaluate stock boundaries? Symmetry 2021, 13, 987. [CrossRef]

43. Hilbig, R.; Knie, M.; Shcherbakov, D.; Anken, R.H. Analysis of behaviour and habituation of fish exposed to diminished gravity in correlation to inner ear stone formation-A sounding rocket experiment (TEXUS 45). In Proceedings of the 20th ESA Symposium on European Rocket and Balloon Programmes and Related Research, Hyere, France, 22-26 May 2011.

44. Lemberget, T.; Mccormick, M.I. Replenishment success linked to fluctuating asymmetry in larval fish. Oecologia 2009, 159, 83-93. [CrossRef]

45. Gagliano, M.; McCormick, M.I. Feeding history influences otolith shape in tropical fish. Mar. Ecol. Prog. Ser. 2004, 278, 291-296. [CrossRef]

46. Swan, C.M.; Palmer, M.A. Preferential feeding by an aquatic consumer mediates non-additive decomposition of speciose leaf litter. Oecologia 2006, 149, 107-114. [CrossRef] [PubMed]

47. Vignon, M.; Morat, F. Environmental and genetic determinant of otolith shape revealed by a non-indigenous tropical fish. Mar. Ecol. Prog. Ser. 2010, 411, 231-241. [CrossRef]

48. Bose, A.P.H.; Zimmermann, H.; Winkler, G.; Kaufmann, A.; Strohmeier, T.; Koblmüller, S.; Sefc, K.M. Congruent geographic variation in saccular otolith shape across multiple species of African cichlids. Sci. Rep. 2020, 10, 12820. [CrossRef] [PubMed]

49. Schulz-Mirbach, T.; Ladich, F.; Plath, M.; Heß, M. Enigmatic ear stones: What we know about the functional role and evolution of fish otoliths. Biol. Rev. 2019, 94, 457-482. [CrossRef] 
50. Burke, N.; Brophy, D.; King, P.A. Otolith shape analysis: Its application for discriminating between stocks of Irish Sea and Celtic Sea herring (Clupea harengus) in the Irish Sea. ICES J. Mar. Sci. 2008, 65, 1670-1675. [CrossRef]

51. Vignon, M. Short-term stress for long-lasting otolith morphology-brief embryological stress disturbance can reorient otolith ontogenetic trajectory. Can. J. Fish. Aquat. Sci. 2018, 75, 1713-1722. [CrossRef] 